\title{
OPTIMIZATION OF SHARIA BANK CUAN IN THE INDUSTRIAL ERA 4.0
}

\author{
*Ridha Alhamdi ${ }^{1}$, Sugianto ${ }^{2}$, Saparuddin Siregar ${ }^{3}$ \\ ${ }^{1,2,3}$ Universitas Islam Negeri Sumatera Utara, Medan \\ E-mail: ${ }^{1)}$ ridhaalhamdi@gmail.com,${ }^{2)}$ sugianto@uinsu.ac.id,${ }^{3)}$ saparuddin.siregar@uinsu.ac.id
}

\begin{abstract}
Is how to develop products and services to boost productivity and competitiveness in the economic and business industries. As for the opportunities owned by Islamic banking to develop products and services to face industry 4.0, namely, the first is qualified human resources, the second is technological sophistication, and the third is the products that society needs in facing the industrial revolution 4.0. The results of this study are that there are several opportunities and challenges faced by Islamic banks in Indonesia in facing the industrial revolution 4.0 in the scope of financial technology (fintech). the three products that society needs in facing the industrial revolution 4.0. The results of this study are that there are several opportunities and challenges faced by Islamic banks in Indonesia in facing the industrial revolution 4.0 in the scope of financial technology (fintech). the three products that society needs in facing the industrial revolution 4.0. The results of this study are that there are several opportunities and challenges faced by Islamic banks in Indonesia in facing the industrial revolution 4.0 in the scope of financial technology (fintech).
\end{abstract}

Keywords: Marketing, Islamic Banks, Fintech, Industrial Revolution 4.0.

\section{INTRODUCTION}

Marketing is a very important part of company. The marketing department is responsible to influence consumers into a series coordinated activities. Marketing activities carried out through a process of planning, organizing, implementation, and control. The process is function of management in marketing activities to meet consumer needs and wants.

Marketing in Islam is a form of muamalah that is justified in Islam, as long as all transactions are protected from prohibited things by sharia provisions. According to Kertajaya (Kertajaya and Sula, 2006: 28), Sharia marketing is a strategic business discipline that directs the process of creating, offering and changing value from an initiator to its stakeholders, which in the whole process is in accordance with the contract and the principles of muamalah (business). ) in Islam.

The development of today's technological era is growing rapidly in such a way and dominates aspects of human life. Currently we are faced with industry 4.0, where everything is closely related to technology. Industry 4.0 is marked by digitalization, which uses technology on all fronts. In industry 4.0, there are 5 things which include Artificial Intelligence (AI), Internet of Things (IOT), human-machine interfaces, robotic and sensor technology and three-dimensional 
(3D) printing technology. ${ }^{1}$ These five technologies are a sign that in this era the industry will enter the virtual world and the use of automation machines that are integrated with the internet.

The industrial revolution 4.0 makes the boundaries between the digital, physical and biological worlds thinner and even disappears. Professor Klaus - the founder of the world economic forum- said that the 4.0 revolution could have a negative impact on governments who stutter and cannot take advantage of fast technological developments. ${ }^{2}$ The use of technology in various fields, one of which is in the economic field, encourages us to think hard to issue product innovations so that they are not swallowed up along with the times. The fintech phenomenon is the delivery of financial products and services through a mix of technology platforms and innovative business models. The origin of fintech comes from Silicon Valley, then extends to New York, London, consumers fulfill their financial needs (saving, investing, making payments).

The demand for banking digitalization is reinforced by various factors driving the development of digital banks in Indonesia, considering that Indonesia is an economy that has great potential to absorb the flow of digitalization. These driving factors are reflected in 3 (three) main aspects, namely digital opportunities, digital behavior and digital transactions. Digital opportunities include demographic potential, digital economic and financial potential, internet usage penetration potential, as well as the potential for increasing consumers. Digital behavior includes ownership of devices and the use of mobile applications (mobile apps). Digital transactions include online trading transactions (e-commerce), digital banking transactions, electronic money transactions, and a decrease in the number of Bank branch offices.

According to OJK in 2016, the national financing (loan) needs reached Rp. 1,600 trillion. But only about Rp. Only 6.00 trillion can be served by banking and other financial industries. This is a great opportunity for fintech start-ups to develop their business in Indonesia, no wonder this sector is also flooded with players. As of the end of June 2018, OJK has recorded 64 fintech companies based on peer-to-peer (P2P) lending ${ }^{3}$ and there are still dozens waiting in line at the back.

In Indonesia, there are also several start-up companies that issue sharia fintech such as Zahir Capital Hub which is a sharia fintech service developed by PT. Zahir International. Zahir Capital Hub offers smart and easy services for companies to get capital investment from credible and trusted sharia partners, in accordance with the sharia corridor.

So far, DSN MUI has encouraged cooperation between Islamic fintech companies and Islamic banking through the DSN-MUI fatwa no: 117/DSN-MUI/II/2018 regarding information technology-based financing services based on sharia principles, which will accelerate the increase in financial market share. sharia in Indonesia.

Seeing this reality, it is a shame if Islamic banking does not take part in developing its products in the form of technology-based products, because in the era of the Industrial Revolution

\footnotetext{
${ }^{1}$ Annisa Dea Widiarini, "Millennials, Get Ready to Welcome the Industrial Revolution 4.0", Kompas.com, https://edukasi.kompas.com/read/2018/10/03/17521731/millenial-cepat-cepat-sambut-revolutionindustri-40, accessed on October 25, 2018

2 Ona Gae Luna, “Industrial Revolution and Indonesia 4.0”, Kumparan, https://kumparan.com/nona-gaeluna1519199971381/revolution-industri-dan-indonesia-4-0, accessed 1 November 2021

${ }^{33}$ Nindya Aldila, "Indonesia is the Most Ready Country to Develop Sharia Fintech", Business Finance, http://finansial.bisnis.com/read/20180707/89/813959/indonesia-negara-paling-ready-developed-fintechsharia, accessed on November 2, 2021
} 
4.0 technological developments will greatly support the development of a technology-literate institution, moreover Islamic banks will lose their market share. if not immediately meet current and future market needs.

\section{IMPLEMENTATION METHOD}

This research is a qualitative research using a descriptive approach, with the intention of interpreting the phenomena that occur and is carried out by involving various existing methods.

\section{RESULTS AND DISCUSSION}

\subsection{Sharia Marketing Strategy}

In this case, sharia marketing is a strategic business discipline that directs the process of creating, offering and changing the value of an initiator which in the whole process is in accordance with the contract and the principles of muamalah (business) in Islam.

The components in the sharia marketing strategy include segmentation, targeting, positioning and differentiation.

\section{Segmentation}

The market consists of many types of customers, products and needs. Marketers must determine which segments offer the best opportunities. Consumers can be grouped and served in a variety of ways based on geographic, demographic, psychographic and behavioral factors. The process of dividing a market into distinct groups of buyers who have different needs, characteristics, or behaviors, who may require separate products or marketing programs is called market segmentation.

\section{Targeting}

After segmenting the Islamic bank, select the segment or segments to enter. This segment is called targeting and with this targeting means an effort to place Islamic bank resources in an efficient manner. Therefore, this targeting is called a fitting strategy or strategy of accuracy. Furthermore, Kotler, Kartajaya, Huan and Liu stated that there are three criteria that must be met by Islamic banks when evaluating and determining which segments to target.

\section{Segmentation}

The market consists of many types of customers, products and needs. Marketers must determine which segments offer the best opportunities. Consumers can be grouped and served in a variety of ways based on geographic, demographic, psychographic and behavioral factors. The process of dividing a market into distinct groups of buyers who have different needs, characteristics, or behaviors, who may require separate products or marketing programs is called market segmentation.

\section{Positioning}

After mapping and placement, Islamic banks must ensure their presence in the minds of customers in the target market. Therefore this strategy is called being strategy or existence strategy. Positioning or determining market position is an activity to formulate product placement in competition and determine a detailed marketing mix. Determining the market position for the products or services of an Islamic bank is very important, so that it can attract customers to buy the products or services offered. Positioning includes offering planning and 
image of Islamic banks/banks so that the target market deems it necessary to position Islamic banks/banks among competitors.

\section{Differentiation}

After the image to be formed in potitioning has been defined, the next step is to align it in a differentiation. Differentiation is defined as the act of devising a set of meaningful differences in the offerings of Islamic banks. However, this offer does not mean mere promises, but must be supported by a tangible form. This differentiation is in the form of content (what to offer) and context (how to offer) and no less important is infrastructure (capability to offer).

\subsection{Islamic Bank Marketing Tactics}

Tactics are activities using various promotional techniques, service to society in seeking market domination. The components of sharia marketing tactics are: marketing-mix and selling.

\section{Marketing-Mix}

In the marketing-mix there are elements known as the 4Ps, namely place (location), product (product), promotion (promotion), price (price). Product and price are components of offers, while place and promotion are components of access. Therefore, the marketing-mix is intended to integrate offers from Islamic banks (company's offer) with available access (company's access).

\section{Selling}

The last element of the sharia marketing tactic is selling. In selling, Islamic banks not only convey the features of the products and services offered, but also the advantages and even solutions of these products or services. Likewise with sharia-based Islamic banks. This Islamic bank must be able to provide solutions for consumers so that consumers will be more loyal to the Islamic bank's products or services. One way is to establish long-term relationships with consumers. In selling, Islamic banks not only convey the features of the products and services offered, but also the advantages and even solutions of these products or services. Islamic banks must be able to provide solutions for their customers so that consumers will be more loyal to the Islamic bank's products or services. One way is to create long-term relationships with customers.

\subsection{Understanding the Industrial Revolution 4.0}

The concept of the industrial revolution 4.0 was first introduced by Professor Klaus Schwab - a well-known economist from Germany - in his book entitled The Fourth Industrial Revolution which states that the concept has changed human life and work. The industrialization of the world began at the end of the 18th century with the invention of the first mechanical loom in 1784. At that time industry was introduced to the facility of mechanical products using water and steam power. Work equipment that initially depended on human and animal labor was eventually shifted to the machine. At this time is considered the birth of the industrial revolution 1.0.

Entering the 20th century which marked the birth of the 2.0 industrial revolution, at that time the introduction of mass products based on the division of labor. The first production line at that time involved a slaughterhouse in Cincinati, Ohio in 1870. The 1970s are considered to be the birth of industry 3.0 marked by the use of electronics and information technology to automate production. In this third generation industry, the first programmable logic controller (PLC) 
appeared, namely the 084-969 modem. Computer-based automation systems also make industrial machines no longer controlled by humans.

We have arrived at the present time, namely the era of the industrial revolution 4.0 which is marked by cyber-physical. Currently, the industry is starting to touch the virtual world, in the form of human, machine and data connectivity, and everything is already everywhere. This term is also known as the Internet of Things (IoT). IoT itself is included in the scope of industry 4.0. In industry 4.0 there are 5 things which include Artificial Intelligence (AI), Internet of Things (IoT), human-

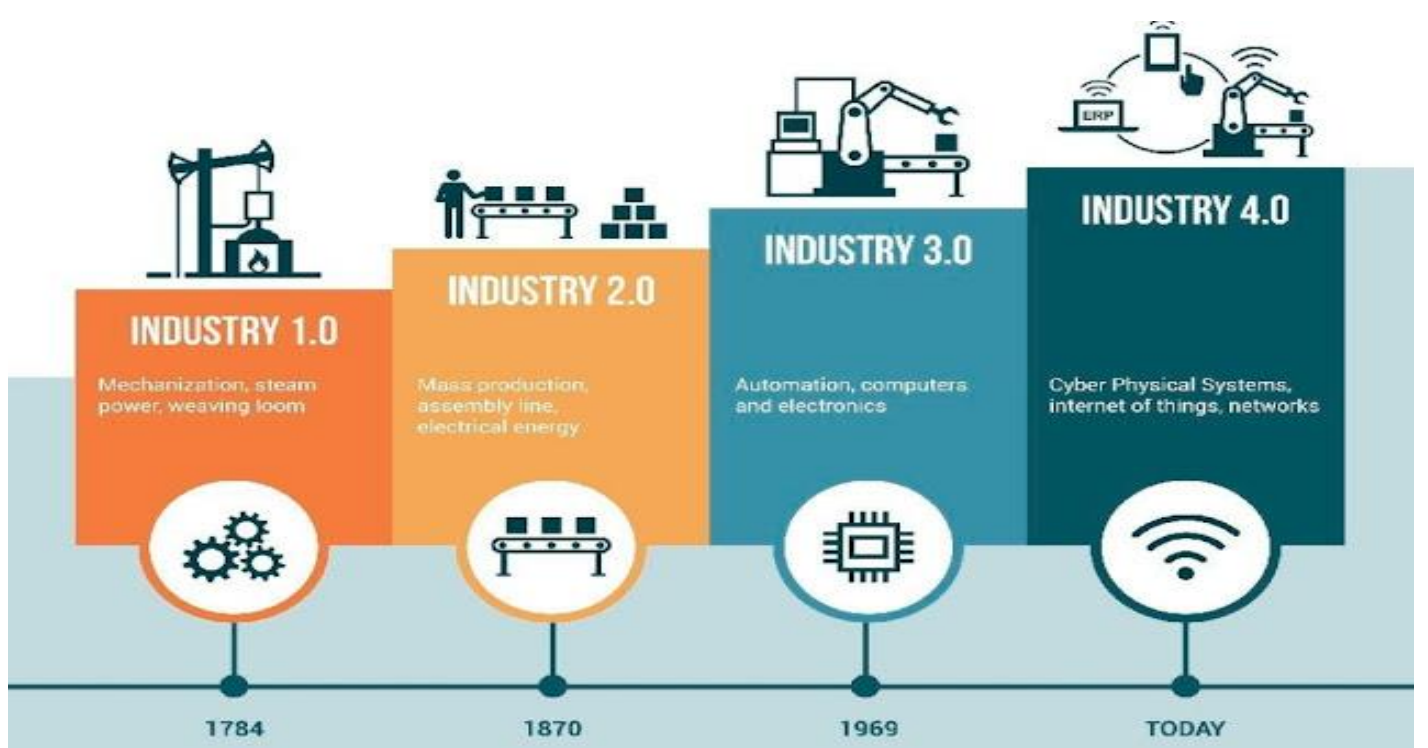

machine interfaces, robotic and sensor technology and three-dimensional (3D) printing technology.

Industry 4.0 itself has indeed been seen in our daily lives such as the presence of smartphones supported by sensor technology, all-digital communication, the use of internet technology in all aspects of life and so on. In 2017 a humanoid robot14 named Sophia based on AI (Artificial Intelligence) technology was introduced to the world and in the same year became the first robot to gain citizenship from a country (Saudi Arabia). ${ }^{4}$ This proves that we cannot deny the presence of the industrial revolution 4.0, because the more we refuse, the more we will be left behind.

President Joko Widodo spoke about the industrial revolution 4.0 which is estimated to be 3,000 times faster than the first generation industrial revolution. This 4.0 industrial revolution certainly has a considerable influence on the industrial world such as the presence of robots in the construction sector that are able to build houses in less than 24 hours with 3D printing technology, robotic hands that can weld materials quickly and assemble various types of vehicles and others.

The digital revolution and the era of disruption are other terms for industry 4.0, called the digital revolution because of the proliferation of computers and automation in all fields. Industry 4.0 is said to be the era of technological disruption because automation and connectivity in a field will make the movement of the industrial world and job competition non-linear. One of the unique characteristics of industry 4.0 is the application of Artificial Intelligence (AI) with the form of

${ }^{4}$ Sophia (robot), https://itechmagz.id/sophia-robot-artificial-intelligence-ai-pertama-di-dunia/ accessed on October 1, 2021 
application being the use of robots to replace human labor so that it is cheaper, more effective and efficient.

A big leap occurred in the industrial sector in the era of the industrial revolution 4.0, where information and communication technology was fully utilized. In this era, the business model also underwent major changes, not only in the production process but also throughout the industrial value chain. Industry 4.0 is predicted to have great potential benefits. Most of the opinions regarding the potential benefits of Industry 4.0 are about improving production speed-flexibility, improving customer service and increasing revenue. The realization of these potential benefits will have a positive impact on the economy of a country. ${ }^{5}$ So like it or not, like it or not, we really have to be ready to face industry 4.0 so that it doesn't get crushed by the progress of the times.

\subsection{Preparation for the Industrial Revolution 4.0}

Industry 4.0 is an approach to control the production process by synchronizing time by unifying and adjusting time. Industry 4.0 is used on three interrelated factors, namely; 1) digitalization and economic interaction with simple techniques to economic networks with complex techniques; 2) digitization of products and services; and 3) new market models.

The presence of the 4.0 industrial revolution that is currently taking place has indeed caused pros and cons in the community. On the one hand, some people think that the advancement of artificial intelligence technology (Artificial Intelligence) in the industrial sector is a necessity that cannot be dammed. However, it is undeniable that the industrial revolution is a threat to mass unemployment in the future.

The good news is that the presence of the Industrial Revolution 4.0 will not have a completely negative impact as previously feared. The World Economic Forum predicts four issues that will affect employment in the future. First, AI technology and robots will create more jobs, not mass unemployment. It is true that automation will cause some jobs to be lost, but on the other hand it is actually bringing new job opportunities in other fields. Economists believe that what will happen in the future is not a lack of job vacancies, but a lack of skills suitable for the type of work in the future.

Second, each city will compete with each other for human resources with the best talents. Competition to get the best talent no longer takes place only between companies, but will increase to be between cities. Along with the development of technology that allows working remotely, people will prefer to live in a city with a technology-friendly environment compared to living in a place closest to the office.

Third, most of the workers in developed countries will become freelancers before 2027 . These freelance workers will be dominated by the millennial generation. On the other hand, it is believed that companies will prefer to recruit freelance workers rather than permanent workers to fill the talent gap they need.

Fourth, the education system has changed from a partial approach to a holistic approach. Mathematics, arts and science lessons which have been seen as separate disciplines are considered irrelevant in filling the competency needs of future jobs. Schools will begin to adopt a project-

${ }^{5}$ Hoedi Prasetyo, "Industry 4.0: A Study of Aspect Classification and Research Development Directions", J@ti Undip: Journal of Industrial Engineering, Vol. 13, No. 1, January 2018 
based curriculum as a bridge to break down the barriers that have hindered the generation of creative thinking.

There are several things that become our concentration in facing the industrial revolution 4.0. According to the Minister of Industry Airlangga Hartarto, there are 4 strategic steps for Indonesia to implement industry 4.0, namely first, the ministry is encouraging the workforce in Indonesia to continue to learn and improve their skills and to understand the use of Internet of Things (IoT) technology or integrate internet capabilities with production lines. in the industry. Second, the use of digital technology to spur productivity and competitiveness for small and medium-sized industries (IKM) so that they are able to penetrate the export market through the e-smart IKM program. This program is an effort to expand the market in the world value chain and face industry 4.0. Third, the national industry is expected to be able to use digital technology such as Big Data, Autonomous Robots, Cybersecurity, Cloud and Augmented Reality. Fourth, technological innovation through the development of startups by facilitating business incubation places.

Industry 4.0 is indeed more targeted at the millennial generation, the generation that is currently considered the most literate and understanding of technological developments. The millennial generation itself is often referred to as the "Y" generation, namely the generation born between the late 1980s and early 2000s.23 This generation is generally characterized by increased use and familiarity with communication, media and digital technology. When viewed from the time period, the millennial generation is currently in a productive age, so it is very possible to prepare human resources from the millennial generation to face the industrial revolution 4.0.

\subsection{Opportunities and Challenges of the Industrial Revolution 4.0 for Islamic Banking}

Indonesia is a country with the fourth largest population in the world. More than $70 \%$ of Indonesia's population is in the productive age range (15 to 64 years). Indonesia's demographic structure is dominated by Generation Z, Millennial Generation, and Generation X so that it has the most prospective consumer segments. The dominance of the three generations, which in fact adapt more quickly to technological developments, is a golden opportunity for the Bank to transform into a digital bank which is expected to offer products and services that will meet consumer needs and expectations. 


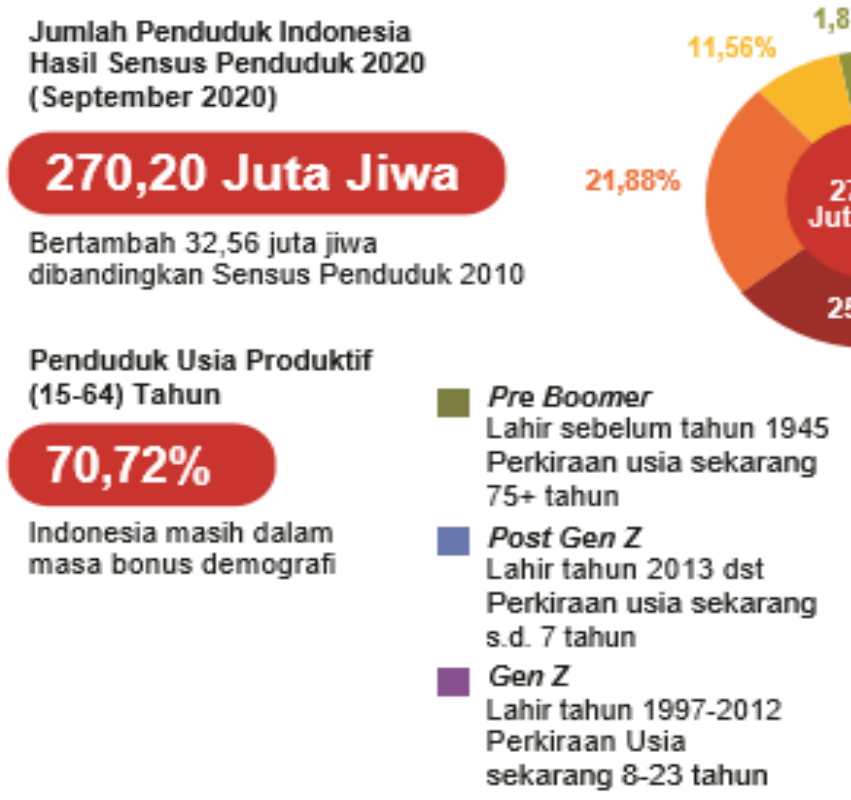

Sumber : Sensus Penduduk 2020 (Badan Pusat Statistik)
$1,87 \% \quad 10,88 \%$

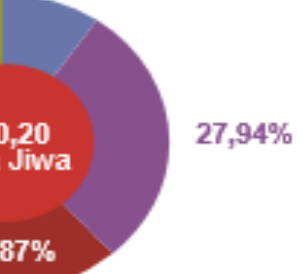

Milenial

Lahir tahun 1991-1996

Perkiraan usia sekarang

24-39 tahun

Gen $X$

Lahir tahun 1965-1980

Perkiraan usia

sekarang 40-55 tahun

Baby Boomer

Lahir tahun 1946-1964

Perkiraan usia

sekarang 56-74 tahun

Banking in Indonesia in its long journey has experienced various phases of the Industrial revolution. Development after development then led to an era which is now called the era of the industrial revolution 4.0, as stated by President Joko Widodo, the industrial revolution 4.0 has encouraged technological innovations that have a disruptive impact or fundamental change to people's lives.

Disruption is not only defined as the phenomenon of today's change (today change) but also reflects the meaning of tomorrow's change (the future change). ${ }^{6}$ Prof. Clayton M. Christensen, a business administration expert from Harvard Business School, explains that the era of disruption has disrupted or damaged pre-existing markets but has also encouraged the development of products or services that were previously unsuspected, creating a diverse consumer base and impacting prices. which is getting cheaper.

The Industrial Revolution 4.0 offers us opportunities as well as threats to the sustainability of even well-established businesses, Islamic banking institutions are no exception. But basically, there are several benefits to be gained with this change. The first is related to product optimization that encourages optimization of business profits. The ability to utilize this technology can also be used as a medium to offer banking services without having to go directly to the field.

The second benefit is related to orientation, meaning that the Industrial Revolution 4.0 can create a flexible customer-oriented market that will help the public in accessing banking products quickly and easily. In this case, the acceleration and ease of accessing banking products, especially

${ }^{6}$ Rhenal Kasali (2017). Straighten Understanding about Disruption.

https://economic.kompas.com/read/2017/05/05/073000626/meluruskan.pemahaman.perti. disruption, accessed on December 5, 2021. 
related to financing, which has been considered difficult and convoluted because of the administrative process, will be greatly helped by the existence of a digitalization system.

The third benefit of the Industrial Revolution 4.0 for Islamic banks is to encourage education and research. That the development of the times does not provide opportunities for those who are stagnant and do not want to learn. Likewise with Islamic banks, even though they already have thousands of loyal customers, it is not impossible that customers will gradually move if the bank does not develop according to the times and practical needs of customers.

From the various benefits obtained by the Industrial Revolution, there are opportunities for Islamic banks to develop their products so that they are up to date according to market developments. Some of the opportunities that the author formulates include:

a. Reliable Human Resources (HR)

In terms of human resources, as stated by the Deputy Governor of BI, Hendar is a problem for all parties, not only from academics and practitioners, but also from regulators and multilateral institutions. BI works In terms of human resources, as said by the Deputy Governor of BI, Hendar is a problem for all parties, not only from academics and practitioners, but also from regulators and multilateral institutions. BI in collaboration with the Islamic Research and Training InstituteIslamic Development Bank (IRTI-IDB) held a Seminar on "Human Capital Development". In the seminar, fully discussed "Producing Competitive Human Capital for Economic Empowerment (Producing Competitive Human Capital for Economic Empowerment)".

The current system of recruiting Islamic banking resources should make technology skills a mandatory standard that must be possessed by applicants, not just communication and marketing skills, not just the ability to master syar'i arguments. In the Industrial Revolution 4.0, the ability to master technology is a measure in controlling market share which has been established so far.

In the field of financial technology, many start-up companies provide financial services at lower costs and easier requirements. In addition, start-up companies are also starting to explore Islamic finance as a business model. This fact, of course, must get serious handling from sharia banking stakeholders if they do not want to suffer the same fate as conventional transport companies whose customers are starting to be abandoned because they are replaced by onlinebased transportation.

b. Technology advances

The next task of Islamic banks is regarding the technological sophistication of this financial industry. To support the success of technology-based products, of course, a reliable information technology system that can be easily accessed by the public is needed.

Besides the ease of access, this information system must be able to record the personal information of the people who apply this product in order to anticipate if there are things that are not desired, such as for example, dispute resolution can be carried out if the customer commits a default.

Advances in information technology are the most dominant thing in the development of the digital-based Islamic banking industry. Software technology and big data28 can be used as risk analysts for potential customers, this is not a difficult thing for technology, because almost everyone has social media that stores their personal data.

c. The need and convenience of banking products 
Banking products that have been known by the public it will be difficult to access it, in the current digital era, banks must dare to evolve into an institution that provides convenience and cheapness in providing financing to the public. Considering that currently many bank activities in terms of financing are being taken over by start-up companies through financial technology or fintech programs. As an intermediary institution, banks should be able to provide answers to their customers' wishes to present digitalable products. Thus, there will be a lot of spaces that will be filled again by this Islamic bank financial institution.

\section{CONCLUSION}

In the Industrial revolution 4.0, Banking has great opportunities in the field of qualified Human Resources so that it is easy to apply technology, the second is the opportunity to use advanced technology that can easily be obtained by Islamic banking institutions, and the third is Islamic banking products that much in demand by customers will be easily accessed via the internet.

Product innovation is the key to Islamic banking to be more useful, competitive and develop more quickly according to the needs of the community. Product innovation must be a priority strategy for Islamic banks, because innovation has an important role in reaching and controlling the ever-changing market. For this reason, the Islamic banking industry is required to develop, be creative and innovate new products. The success of the Islamic banking system in the future will depend a lot on the ability of Islamic banks to present attractive, competitive products and provide ease of transactions, in accordance with the needs of the community and the market industry. To develop varied and attractive products.

\section{REFERENCES}

Aam Slamet Rusydiana, "Bagaimana Mengembangkan Industri Fintech Syariah di Indonesia?

Adrian Teja, "Indonesian Fintech Business: New Innovations or Foster and Collaborate in Business Ecosystems?", The Asian Journal of Technology Management, Vol 10 No 1 (2017)

Agung, A.M. Lilik. "Dari Disrupsi Menuju Kenormalan Baru" https://news.detik.com/kolom/d5073882/dari-disrupsi-menuju-kenormalan-baru

Aldila, Nindya. "Índonesia Negara Paling Siap Kembangkan Fintech Syariah”, FinansialBisnis, http://finansial.bisnis.com/read/20180707/89/813959/indonesia-negara-paling-siap-

kembangkan-fintech- syariah.

Dea Widiarini, Annisa. "Milenial, Siap-siap Sambut Revolusi Industri 4.0". Kompas.com. https://edukasi.kompas.com/read/2018/10/03/17521731/milenial- siap-siap-sambut-revolusiindustri-40

Hermawan Kertajaya, Muhammad Syakir Sula (2006), Syariah Marketing, Jakarta : Mizan.

Jeko I.R, "Bentuk Capital Hub, Zahir Bidik Industri Fintech Syariah, Liputan6, https://www.liputan6.com/tekno/read/3630229/bentuk-capital-hub-zahir-bidikindustri-fintech-syariah.

Kaeser, Joe. "The World is Changing, Here"s How Companies must adapt", World Economic Forum, https://www.weforum.org/agenda/2018/01/the-world-is-changing-here-s-howcompanies-must-adapt/ diakses tanggal 15 Desember 2021 
Kasali, Rhenal. "Meluruskan Pemahaman soal Disruption". Kompas. https://ekonomi.kompas.com/read/2017/05/05/073000626/meluruskan.pemaham a n.soal. disruption.

Kholidah, Nur. Peranan Kearifan Lokal Dalam Pengembangan Ekonomi Syariah Pada Era Revolusi Industri 4.0, Jurnal Ilmiah Neraca FEB - UMPP, Vol 15, No. 1, 14-21, 2019. ISSN 2745-5750.

Luna, Ona Gae. "Revolusi Industri dan Indonesia 4.0", Kumparan, https://kumparan.com/nonagae- luna1519199971381/revolusi-industri-dan-indonesia-4-0.

Murdaningsih, Dwi. "MUI Dorong Kerjasama Fintech Syariah dan Perbankan Syariah", Republika, https://republika.co.id/berita/ekonomi/syariah-ekonomi/18/07/06/pbg330368mui-dorong- kerjasama-fintech-syariah-dan-perbankan-syariah.

Nur Ilham, R. ., Arliansyah, A., Juanda, R., Multazam, M. ., \& Saifanur, A. . (2021). RELATHIONSIP BETWEEN MONEY VELOCITY AND INFLATION TO INCREASING STOCK INVESTMENT RETURN: EFFECTIVE STRATEGIC BY JAKARTA AUTOMATED TRADING SYSTEM NEXT GENERATION (JATS-NG) PLATFORM. International Journal of Economic, Business, Accounting, Agriculture Management and Sharia Administration (IJEBAS), 1(1), 87-92. https://doi.org/10.54443/ijebas.v1i1.27

Pendekatan Interpretive Structural Model (ISM), Jurnal Al- Muzara'ah, Vol 6 No.2 2018

Pollari, Ian. The Rise of Fintech Opportunities and Challenges. The Finsia Journal of Applied Finance. ISSUE 3, 2016.

Riyadi, A. ., Khaddafi, M. ., F, F., F, F., \& Nur Ilham, R. . (2021). INTERNAL FACTOR OF SYSTEMAMTIC RISK MODEL WITH INFORMATION TECHNOLOGY AS INTERVENING VARIABLES TO INCREASING QUALITY OF GOVERNMENT FINANCIAL REPORTS IN INDONESIA: ACTUAL CASE FROM RIAU ISLAND PROVINCE. MORFAI JOURNAL, 1(1), 22-35. https://doi.org/10.54443/morfai.v1i1.13

Sandy, Kunthi Fahmar. BI dan IDB Tingkatkan Kualitas SDM Ekonomi Syariah https://ekbis.sindonews.com/berita/1108174/33/bi-dan-idb-tingkatkan-kualitas-sdmekonomi-syariah

Supriyanto, D., Aravik, H., \& Choiriyah, C. (2021). Analisis Perilaku Milenial Dalam Keputusan Menjadi Nasabah Bank Syariah Di Era Revolusi 4.0 (Studi Kasus Mahasiswa Prodi Perbankan Syariah Stebis Igm Palembang). Jurnal Ilmiah Mahasiswa Perbankan Syariah (JIMPA), 1(2), 185-192. https://doi.org/10.36908/jimpa.v1i2.29

Suriana, S. (2021). THE INFLUENCE OF ACCOUNTABILITY AND TRANSPARENCY OF FINANCIAL MANAGEMENT OF VILLAGE FUNDS ON VILLAGE GOVERNMENT PERFORMANCE IN KOTARIH BARU VILLAGE KOTARIH DISTRICT SERGAI REGENCY. International Journal of Educational Review, Law And Social Sciences (IJERLAS), 1(1), 53-66. https://doi.org/10.54443/ijerlas.v1i1.30 
Volume 2 Issue 1 (2022)

OPTIMIZATION OF SHARIA BANK CUAN IN THE INDUSTRIAL ERA 4.0 DOI: $10.54443 /$ ijerlas.v2i1.128 